\title{
4-[(3,5-Dimethyl-1H-pyrazol-1-yl)methyl]-4-methyl-2- phenyl-4,5-dihydrooxazole
}

\author{
Sara Hajib ${ }^{1}$, Anouar Alami ${ }^{2, *}$, Hassane Faraj $^{2}$ and Younas Aouine ${ }^{3}(\mathbb{C}$ \\ 1 Doctoral Training "Bioactive Molecules, Health and Biotechnology", Center of Doctoral Studies \\ "Sciences and Technology", Faculty of Sciences Dhar Mahraz, Sidi Mohamed Ben Abdellah University, \\ Fez 30000, Morocco \\ 2 Organic Chemistry Laboratory (LCO), Faculty of Sciences Dhar El Mahraz, Sidi Mohammed Ben Abdellah \\ University, Fez 30000, Morocco \\ 3 Organic Chemistry Laboratory (LCO), Faculty of Sciences, Ibn Zohr University, P.B 8106, Cité Dakhla, \\ Agadir 80060, Morocco \\ * Correspondence: alamianouar@yahoo.fr; Tel.: +212-661-796-480; Fax: +212-535-733-171
}

Received: 30 June 2019; Accepted: 16 July 2019; Published: 19 July 2019

\begin{abstract}
The compound, 4-[(3,5-dimethyl-1H-pyrazol-1-yl)methyl]-4-methyl-2-phenyl-4,5-dihydrooxazole 2 was prepared in high yield, through nucleophilic substitution reaction of the $O$-tosyl oxazoline derivative 1, by heating in dimethyl sulfoxide (DMSO) and in presence of $\mathrm{KOH}$ as base. The structure of the synthesized compound was established on the basis of NMR spectroscopy $\left({ }^{1} \mathrm{H},{ }^{13} \mathrm{C}\right)$, MS data and elemental analysis.
\end{abstract}

Keywords: oxazoline; pyrazole; $N$-alkylation; 2D NMR

\section{Introduction}

Five-membered heterocycles are a very important class of molecules because of their wide range of applications in various fields. Pyrazole is the core of this family of heterocycles and it is associated with different biological activities, such as: antimycobacterial [1], inflammatory [2], anticancer [3,4], antimicrobial [5], antibacterial [6], anti-tubercular [7]. It is also used as a herbicide, fungicide [8] and insecticide [9]. In addition to its biological profile, pyrazole is also used as a precursor in organic synthesis.

In the continuation of our research concerning heterocyclic amino acids and their precursors [10-14], we described in this short note our results concerning the synthesis of a new pyrazole compound, 4-[(3,5-dimethyl-1H-pyrazol-1-yl)methyl]-4-methyl-2-phenyl-4,5-dihydrooxazole, an oxazolinic precursor of heterocyclic amino acids via nucleophilic substitution reaction of the (4-methyl-2-phenyl4,5-dihydrooxazol-4-yl)methyl-4-methylbenzenesulfonate and the 3,5-dimethyl-1 $\mathrm{H}$-pyrazole. The title compound was characterized by spectroscopic techniques, such as 1D and 2D NMR spectroscopy, mass spectrometry (MS) and elemental analysis.

\section{Results}

This paper is dedicated to the synthesis of the precursor of 3-(pyrazol-1-yl)-alanine. Our synthesis strategy is based on the nucleophilic substitution of the $O$-tosyl group present in the oxazoline ring 1 with pyrazole nucleus. The starting (4-methyl-2-phenyl-4,5-dihydrooxazol-4-yl)methyl-4-methylbenzenesulfonate 1 was prepared in two steps, from the commercially available 2-amino-2-methyl propan-1,3-diol in first time, then followed by tosylation in the presence of pyridine according to the method recommended by El Hajji [15]. The O-tosylated oxazoline 1 thus obtained was subjected under the action of pyrazole using a superbase (KOH-DMSO) in order to synthesize the new biheterocyclic compound $\mathbf{2}$ (Scheme 1 ). 
The use of a super base (KOH-DMSO) proved necessary to realize the substitution of -OTs group by pyrazole.

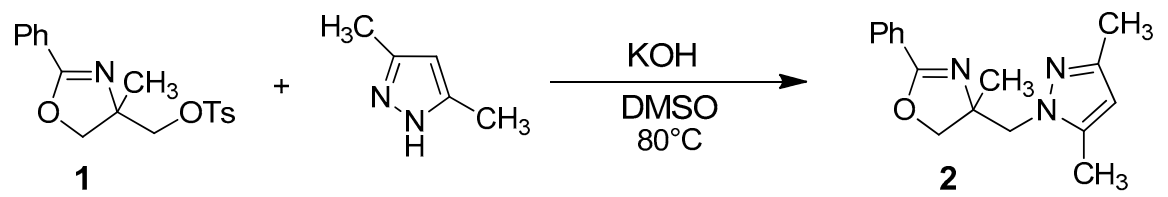

Scheme 1. Synthesis strategy for compound 2.

The structure of the product obtained was established on the basis of standard spectroscopic methods (1D, 2D NMR), mass spectrometry and elemental analysis.

The ${ }^{1} \mathrm{H}-\mathrm{NMR}$ spectrum of compound 2 recorded in chloroform presents, in addition to the signals attributed to aromatic and aliphatic protons, two singlets at 1.36 and $2.18 \mathrm{ppm}$ corresponding successively to the methyl groups $\mathrm{CH}_{3}(12)$ and $\mathrm{CH}_{3}\left(3^{\prime}\right)$. It shows that the 2 methyl radicals of the pyrazole nucleus are not equivalent. The methyl in position 3 is more deblinded than that in position 5; this is due to its different chemical environment. The ${ }^{1} \mathrm{H}-\mathrm{NMR}$ also shows a doublet between 2.266 and $2.268 \mathrm{ppm}$ with a coupling constant $J=0.60 \mathrm{~Hz}$, corresponding to the methyl group $\mathrm{CH}_{3}\left(5^{\prime}\right)$ which explains the correlation observed with $\mathrm{C}_{4}-\mathrm{H}$ proton in the homonuclear NMR-2D spectrum (Figure 1). It presents also a quartet between 4.07 and $4.2 \mathrm{ppm}$ attributed to $-\mathrm{CH}_{2}-\mathrm{N}$ protons with a coupling constant in the order of $J=14.40 \mathrm{~Hz}$. The $-\mathrm{CH}_{2}-\mathrm{O}$ protons of the oxazoline ring are chemically non-equivalents since they are in $\alpha$ of asymmetric carbon and resonate as an $\mathrm{AB}$ system (centered between $4.04 \mathrm{ppm}$ and $4.94 \mathrm{ppm}$ ) with a coupling constant in the order of $J=8.70 \mathrm{~Hz}$. On the other side, the NMR $-{ }^{13} \mathrm{C}$ spectrum of compound 2, shows in particular three signals at $11.60,13.46$ and $25.10 \mathrm{ppm}$ attributed to the carbons of the methyl groups $-\mathrm{CH}_{3}$ and a signal at $59.95 \mathrm{ppm}$ corresponding to the carbon $\mathrm{C}_{6}-\mathrm{N}$ of the pyrazole-oxazoline junction. The asymmetric $\mathrm{C}_{7}$ carbon of the oxazoline ring resonates around $71.90 \mathrm{ppm}$ with no correlation observed in the heteronuclear NMR-2D spectrum (Figure 2). Likewise, a signal to $163.65 \mathrm{ppm}$ attributed to the $\mathrm{C}_{10}$ quaternary carbon of the oxazoline ring also represents no correlation. The heteronuclear NMR spectrum (Figure 2) shows also that there is a correlation between the two doublets of the $\mathrm{AB}$ system and the $75.79 \mathrm{ppm}$ signal corresponding to the carbon $\mathrm{C}_{8}-\mathrm{O}$ of oxazoline ring, and the $\mathrm{CH}_{2}-\mathrm{N}$ protons are correlated with the $59.56 \mathrm{ppm}$ signal corresponding to the carbon $\mathrm{C}_{6}-\mathrm{N}$ of the pyrazole-oxazoline. This finding is in perfect agreement with the difference in the electronegativity of the oxygen atom and that of nitrogen. The definite assignment the chemical shifts of protons and carbons are shown in the Table 1 below.

Table 1. (300.13 MHz) and ${ }^{13} \mathrm{C}(75.47 \mathrm{MHz}) \mathrm{NMR}$ spectral data for compound 2 in $\mathrm{CDCl}_{3}$, including results obtained by homonuclear 2D shift-correlated and heteronuclear 2D shift-correlated HSQC $\left({ }^{1} J_{\mathrm{CH}}\right)$. Chemical shifts $(\delta$ in ppm) and coupling constants $(\mathrm{J}$ in $\mathrm{Hz})$.

\begin{tabular}{ccccc}
\hline Position & $\delta_{\mathrm{H}}$ & $\delta_{\mathrm{C}}$ & Correlation $\mathrm{H}-\mathrm{H}$ & Correlation C-H \\
\hline $\mathbf{3}$ & - & 147.55 & - & - \\
\hline $\mathbf{3}^{\prime}$ & $2.18(\mathrm{~s})$ & 13.46 & $3 \mathrm{H}^{3^{\prime}}-3 \mathrm{H}^{3^{\prime}}$ & $\mathrm{C}^{3^{\prime}}-3 \mathrm{H}^{3^{\prime}}$ \\
\hline $\mathbf{4}$ & $5.69(\mathrm{~s})$ & 105.06 & $1 \mathrm{H}^{4}-1 \mathrm{H}^{4}$ & $\mathrm{C}^{4}-1 \mathrm{H}^{4}$ \\
\hline $\mathbf{5}$ & - & 140.25 & - & - \\
\hline $\mathbf{5}^{\prime}$ & $2.266-2.268(\mathrm{~d}, J=0.60)$ & 11.60 & $\begin{array}{c}3 \mathrm{H}^{5^{\prime}}-3 \mathrm{H}^{5^{\prime}} \\
3 \mathrm{H}^{5^{\prime}}-1 \mathrm{H}^{4}\end{array}$ & $\mathrm{C}^{5^{\prime}}-3 \mathrm{H}^{5^{\prime}}$ \\
\hline $\mathbf{6}$ & $4.096-4.2(\mathrm{q}, J=14.40)$ & 55.95 & $2 \mathrm{H}^{6}-2 \mathrm{H}^{6}$ & $\mathrm{C}^{6}-2 \mathrm{H}^{6}$ \\
\hline $\mathbf{7}$ & - & 71.90 & - & - \\
\hline $\mathbf{8}$ & $4.042-4.939(\mathrm{AB}, J=8.70)$ & 75.79 & $2 \mathrm{H}^{8}-2 \mathrm{H}^{8}$ & $\mathrm{C}^{8}-2 \mathrm{H}^{8}$ \\
\hline $\mathbf{1 0}$ & - & 163.65 & - & - \\
\hline $\mathbf{1 2}$ & $1.36(\mathrm{~s})$ & 25.10 & $3 \mathrm{H}^{12}-3 \mathrm{H}^{12}$ & $\mathrm{C}^{12}-3 \mathrm{H}^{12}$ \\
\hline $\mathbf{1 3 - 1 8}$ & $7.35-7.90(\mathrm{~m})$ & $127.70-131.11$ & $5 \mathrm{H}_{\text {arom }}-5 \mathrm{H}_{\text {arom }}$ & $5 \mathrm{C}_{\text {arom }}-5 \mathrm{H}_{\text {arom }}$ \\
\hline
\end{tabular}




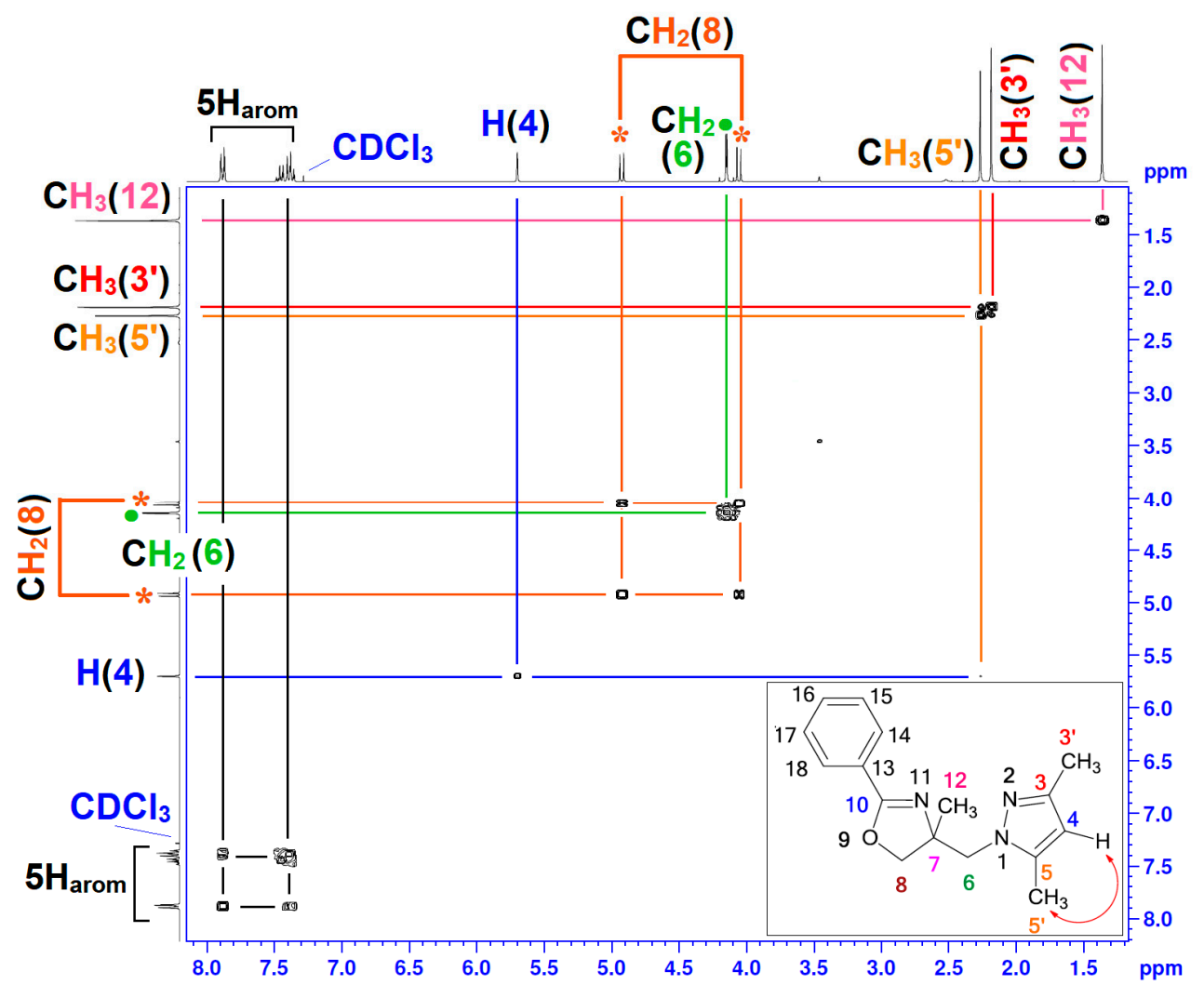

Figure 1. ${ }^{1} \mathrm{H}-{ }^{1} \mathrm{H}$ correlation spectroscopy identifies coupling between protons in compound 2.

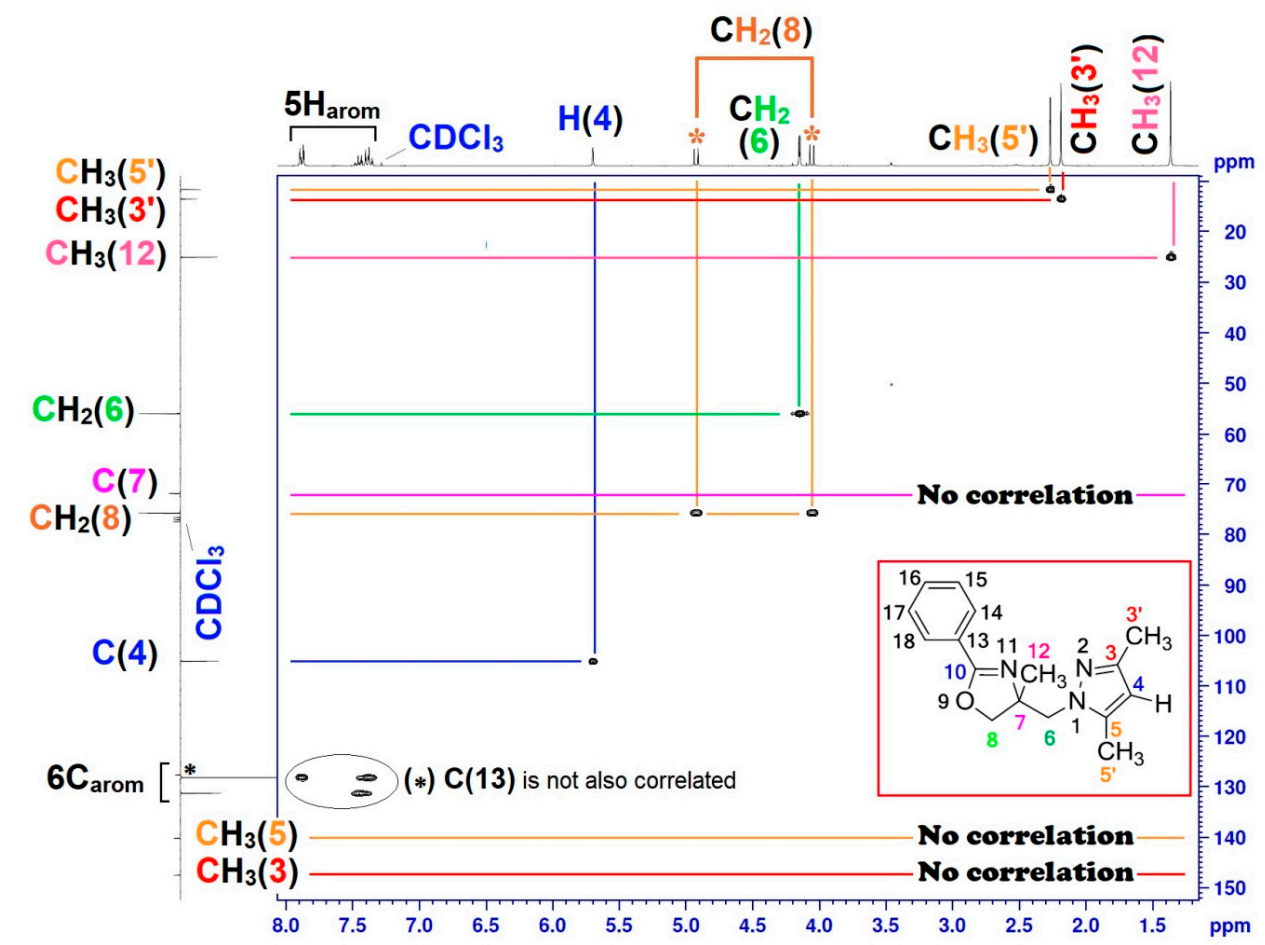

Figure 2. ${ }^{1} \mathrm{H}_{-}{ }^{13} \mathrm{C}$ 2D correlation spectroscopy identifies coupling between protons and carbons in compound 2. 


\section{Materials and Methods}

The solvents used have been purified using standard techniques. Commercial reagents were purchased from Sigma-Aldrich (St. Louis, MO, USA). The melting point was determined using a Kofler Bench device. The NMR spectra (1D and 2D) were recorded in deuterated chloroform on an AM 300 Bruker spectrometer (300.13 MHz for proton and $75.47 \mathrm{MHz}$ for carbon 13) at the Cité d'Innovation of Mohammed Ben Abdallah University in Fez. Chemical displacements are given in ppm and coupling constants in Hz. The reactions were monitored by TLC on silica gel plates (Fertigplatten Kieselgel, $\left.60 \mathrm{~F}_{254}\right)$ and the plates were visualized under a UV lamp (250-365 nm). Mass spectra were recorded on a PolarisQ Ion Trap GC/MSn Mass Spectrometer (City of Innovation, USMBA-Fez, Morocco). Elemental analysis was performed with Flash 2000 EA 1112, Thermo Fisher Scientific-Elemental Analyzer (CNRST-Rabat, Morocco).

To (0.762 g, $7.94 \mathrm{mmol})$ of 3,5-dimethyl- $1 \mathrm{H}$-pyrazole (1.2 eq.) in $15 \mathrm{~mL}$ of DMSO, (0.891 g, $15.88 \mathrm{mmol}$ ) of potassium hydroxide (2.4 eq.) is added in small portions $(\mathrm{KOH})$. The mixture is left shaking for one hour at $80^{\circ} \mathrm{C}$, and then we add drop by drop for $20 \mathrm{~min},(2.284 \mathrm{~g}, 6.62 \mathrm{mmol})$ of the $\mathrm{O}$-tosylated oxazoline 1 diluted in $10 \mathrm{~mL}$ of DMSO. Once the addition is complete, the reaction is maintained at the same temperature $\left(80^{\circ} \mathrm{C}\right)$ for $24 \mathrm{~h}$, and as soon as the reaction is completed, $200 \mathrm{~mL}$ of water is added to the reaction mixture and then extracted by dichloromethane $(6 \times 30 \mathrm{~mL})$. Then, the organic layer is washed with water $(3 \times 20 \mathrm{~mL})$, dried and concentrated. The resulting oil is purified by column chromatography of silica gel (ethyl acetate/hexane).

Yield $=82 \%$ (White solid); m.p. $=161-163{ }^{\circ} \mathrm{C} .{ }^{1} \mathrm{H}-\mathrm{NMR}\left(\mathrm{CDCl}_{3}, \delta_{\mathrm{H}} \mathrm{ppm}\right): 1.36\left(\mathrm{~s}, 3 \mathrm{H}, \mathrm{CH}_{3}-\mathrm{Oxaz}\right)$, $2.18\left(\mathrm{~s}, 3 \mathrm{H}, \mathrm{CH}_{3}\left(3^{\prime}\right)\right), 2.266-2.268\left(\mathrm{~d}, 3 \mathrm{H}, \mathrm{CH}_{3}\left(5^{\prime}\right), J=0.60 \mathrm{~Hz}\right), 4.096-4.2\left(\mathrm{q}, 2 \mathrm{H}, \mathrm{CH}_{2}-\mathrm{N}, J=14.40 \mathrm{~Hz}\right)$, 4.04-4.93 (2H, CH $-\mathrm{Oxaz}, \mathrm{AB}, J=8.70 \mathrm{~Hz}), 5.69\left(\mathrm{~s}, 1 \mathrm{H}, \mathrm{C}_{4}-\mathrm{H}\right), 7.35-7.90\left(\mathrm{~m}, 5 \mathrm{H}_{\text {arom }}\right) .{ }^{13} \mathrm{C}-\mathrm{NMR}$ $\left(\mathrm{CDCl}_{3}, \delta_{\mathrm{C}} \mathrm{ppm}\right): 11.60\left(\mathrm{CH}_{3}\left(5^{\prime}\right)\right), 13.46\left(\mathrm{CH}_{3}\left(3^{\prime}\right)\right), 25.10\left(\mathrm{CH}_{3}-\mathrm{Oxaz}\right), 55.95\left(\mathrm{CH}_{2}-\mathrm{N}\right), 71.90\left(\mathrm{C}_{7}\right)$, $75.79\left(\mathrm{CH}_{2}\right.$-Oxaz $), 105.06\left(\mathrm{C}_{4}\right), 127.70-131.31\left(6 \mathrm{C}_{\text {arom }}\right), 140.25\left(\mathrm{C}_{5}\right), 147.55\left(\mathrm{C}_{3}\right), 163.65\left(\mathrm{C}_{10}\right)$. MS $m / z(\%)=270.14[\mathrm{M}+1]$ (100). Calcd. for $\mathrm{C}_{16} \mathrm{H}_{19} \mathrm{~N}_{3} \mathrm{O}(\%)$ : C, 71.35; $\mathrm{H}, 7.11 ; \mathrm{N}, 15.60$; Found (\%): C 71.16, H 7.11, N 14.94. The supporting ${ }^{13} \mathrm{C}-\mathrm{NMR},{ }^{1} \mathrm{H}-\mathrm{NMR},{ }^{1} \mathrm{H}-{ }^{1} \mathrm{H} N M R,{ }^{1} \mathrm{H}_{-}-{ }^{13} \mathrm{C}$ NMR, mass spectra and elemental analysis are presented in the Supplementary Materials file.

\section{Conclusions}

The synthesis of 4-[(3,5-dimethyl-1H-pyrazol-1-yl)methyl]-4-methyl-2-phenyl-4,5-dihydrooxazole was performed by $\mathrm{N}$-alkylation reaction with good yield. The structure of the product was confirmed by the usual spectroscopic methods.

Supplementary Materials: The following are available online, Figure S1: ${ }^{13} \mathrm{C}-\mathrm{NMR}$ spectrum of compound 2, Figure S2: ${ }^{1} \mathrm{H}-\mathrm{NMR}$ spectrum of compound 2, Figure S3: Homonuclear ${ }^{1} \mathrm{H}-{ }^{1} \mathrm{H}$ spectrum of compound 2, Figure S4: Heteronuclear ${ }^{1} \mathrm{H}_{-}{ }^{13} \mathrm{C}$ spectrum of compound 2, Figure S5: ${ }^{1} \mathrm{H}-{ }^{1} \mathrm{H}$ correlation spectroscopy identifies coupling between protons in compound 2, Figure S6: ${ }^{1} \mathrm{H}^{-13} \mathrm{C}$ 2D correlation spectroscopy identifies coupling between protons and carbons in compound 2, Figure S7: Mass spectrum of compound 2, Figure S8: Elemental analysis of compound 2.

Author Contributions: S.H. performed the experiments; H.F., A.A. conceived and designed the experiments; A.A. supervise the research activity; A.A., Y.A. Analyzed the data and wrote the paper. All authors read and approved the final manuscript.

Funding: This research received no external funding.

Acknowledgments: This work was supported by Sidi Mohammed Ben Abdellah University (USMBA).

Conflicts of Interest: The authors declared that they have no conflict of interest as regards this work.

\section{References}

1. Takate, S.J.; Shinde, A.D.; Karale, B.K.; Akolkar, H.; Nawale, L.; Sarkar, D.; Mhaske, P.C. Thiazolyl-pyrazole derivatives as potential antimycobacterial agents. Bioorg. Med. Chem. Lett. 2019, 29, 1199-1202. [CrossRef] [PubMed] 
2. Hassan, G.S.; Abdel Rahman, D.E.; Abdelmajeed, E.A.; Refaey, R.H.; Alaraby Salem, M.; Nissan, Y.M. New pyrazole derivatives: Synthesis, anti-inflammatory activity, cycloxygenase inhibition assay and evaluation of mPGES. Eur. J. Med. Chem. 2019, 171, 332-342. [CrossRef] [PubMed]

3. Ran, F.; Liu, Y.; Zhang, D.; Liu, M.; Zhao, G. Discovery of novel pyrazole derivatives as potential anticancer agents in MCL. Bioorg. Med. Chem. Lett. 2019, 29, 1060-1064. [CrossRef] [PubMed]

4. Shi, J.B.; Tang, W.J.; Qi, X.B.; Li, R.; Liu, X.H. Novel pyrazole-5-carboxamide and pyrazole-pyrimidine derivatives: Synthesis and anticancer activity. Eur. J. Med. Chem. 2015, 90, 889-896. [CrossRef] [PubMed]

5. Sayed, G.H.; Azab, M.E.; Anwer, K.E.; Raouf, M.A.; Negm, N.A. Pyrazole, pyrazolone and enaminonitrile pyrazole derivatives: Synthesis, characterization and potential in corrosion inhibition and antimicrobial applications. J. Mol. Liq. 2018, 252, 329-338. [CrossRef]

6. Prasath, R.; Bhavana, P.; Sarveswari, S.; Ng, S.W.; Tiekink, E.R.T. Efficient ultrasound-assisted synthesis, spectroscopic, crystallographic and biological investigations of pyrazole-appended quinolinyl chalcones. J. Mol. Struct. 2015, 1081, 201-210. [CrossRef]

7. Xu, Z.; Gao, C.; Ren, Q.-C.; Song, X.-F.; Feng, L.-S.; Lv, Z.-S. Recent advances of pyrazole-containing derivatives as anti-tubercular agents. Eur. J. Med. Chem. 2017, 139, 429-440. [CrossRef] [PubMed]

8. Lamberth, C. Pyrazole Chemistry in Crop Protection. Heterocycles 2007, 71, 1467-1502. [CrossRef]

9. Lahm, G.P.; Cordova, D.; Barry, J.D. New and selective ryanodine receptor activators for insect control. Bioorg. Med. Chem. 2009, 17, 4127-4133. [CrossRef] [PubMed]

10. Aouine, Y.; Faraj, H.; Alami, A.; El Hallaoui, A.; Elachqar, A.; El Hajji, S.; Kerbal, A.; Labriti, B.; Martinez, J.; Rolland, V. Synthesis of new triheterocyclic compounds, precursors of biheterocyclic amino acids. J. Mar. Chim. Heterocycl. 2008, 7, 44-49.

11. Aouine, Y.; Faraj, H.; Alami, A.; El Hallaoui, A.; Elachqar, A.; Kerbal, A. Simple and efficient synthesis of racemic 2-(tert-Butoxycarbonylamino)-2- methyl-3-(1H-1,2,4-triazol-1-yl)propanoic acid, a new derivative of $\beta$-(1,2,4-Triazol-1-yl)alanine. Molecules 2011, 16, 3380-3390. [CrossRef] [PubMed]

12. Aouine, Y.; Faraj, H.; Alami, A.; El Hallaoui, A.; Elachqar, A.; El Hajji, S.; Labriti, B.; Kerbal, A. Triheterocyclic compounds, oxazolinic precursors of biheterocyclic amino acids, Part II: Phenothiazine derivatives and structural study of regioisomers through 1H-15N 2DNMRHMBC. J. Mar. Chim. Heterocycl. 2014, 13, $39-47$.

13. Aouine, Y.; Alami, A.; El Hallaoui, A. N,N-dibenzyl-1-(1-[(4-methyl-2-phenyl-4,5-dihydrooxazol4-yl)methyl)] -1H-1,2,3-triazol-4-yl)methanamine. Molbank 2014, 2014, M819. [CrossRef]

14. Boukhssas, S.; Aouine, Y.; Faraj, H.; Alami, A.; El Hallaoui, A.; Bekkari, H. Synthesis, Characterization, and Antibacterial Activity of Diethyl 1-((4-Methyl-2-phenyl-4,5-dihydrooxazol-4-yl)methyl)-1H-1,2,3triazole-4,5-dicarboxylate. J. Chem. 2017, 2017, 4238360. [CrossRef]

15. Atmani, A.; El Hallaoui, A.; El Hajji, S.; Roumestant, M.L.; Viallefont, P. From Oxazolines to Precursors of Aminoacids. Synth. Commun. 1991, 21, 2383-2390. [CrossRef] 